\title{
Finite Element Analysis of An Evaporation System to Synthesize Kesterite thin Films*
}

\author{
Carlos Eduardo Rondón Almeyda** \\ Mónica Andrea Botero Londoño*** \\ Rogelio Ospina Ospina $a^{* * * *}$
}

\author{
Received: 15/04/2020 - Accepted: 06/06/2020 \\ https://doi.org/10.22395/rium.v20n38a3
}

\begin{abstract}
Currently, there is an interest within the scientific community in thin-film solar cells with a Kesterite $\left(\mathrm{Cu}_{2} \mathrm{ZnSnS}_{4}\right)$ type absorber layer, since they report a theoretical efficiency greater than $32 \%$. The synthesis of Kesterites by evaporation has allowed for efficiencies at the laboratory level of $11.6 \%$. Although these are good results, the design of the evaporation chamber and the distribution of the electrodes is essential to control synthesis parameters and evaporate each precursor in the corresponding stage. This project seeks to design an evaporation chamber that can achieve a vacuum of $10^{-5}$ mbar, increase the deposition surface and avoid each precursor evaporation in a non-corresponding stage. This last objective was studied using Comsol multiphysics R. (licensed product) software, with the adequate disposition of metallic precursors (zinc, copper, and tin) determined by analyzing heat distribution. It was concluded that the lower the evaporation temperature of the precursor, the smaller the height of the copper electrode in the system. This is because, with a lower height the concentration of heat in the container is lower.
\end{abstract}

Keywords: absorber-layer; Comsol; CZTS; evaporation; finite-elements; heat-distribution; kesterite; thin film solar cells.

This article is derived from research and was financed by Universidad Industrial de Santander

** Master in Materials Engineering, Universidad Industrial de Santander. Email: caedroal@correo.uis.edu.co. Orcid: https://orcid.org/0000-0002-5176-1243

*** Doctor in Physical Sciences. Plant teacher Universidad Industrial de Santander. Email: mabotero@saber.uis. edu.co. Orcid: https://orcid.org/0000-0003-1706-3182

**** Doctor in Materials Engineering, Science and Technology. Plant teacher Universidad Industrial de Santander. Email: rospinao@saber.uis.edu.co. Orcid: https://orcid.org/0000-0002-7392-8059 


\title{
Análisis de elementos finitos de un sistema de evaporación para sintetizar películas delgadas de kesterita
}

\begin{abstract}
Resumen
Actualmente, existe un interés dentro de la comunidad científica por las células solares de película delgada con una capa absorbente de kesterita $(\mathrm{Cu} 2 \mathrm{ZnSnS} 4)$, debido a que tienen una eficiencia teórica de más del $32 \%$. La síntesis de kesteritas por evaporación ha permitido un nivel de eficiencia en el laboratorio del $11.6 \%$. Si bien estos son buenos resultados, el diseño de la cámara de evaporación y la distribución de electrodos son esenciales para controlar los parámetros de síntesis y evaporar cada precursor en la etapa correspondiente. Este proyecto busca diseñar una cámara de evaporación que pueda alcanzar un vacío de 10-5 mbar, aumentar la deposición de superficies e impedir la evaporación de cada precursor en una etapa distinta a la correspondiente. Este último objetivo fue estudiado usando el programa Comsol multiphysics R (producto licenciado), con la adecuada disposición de precursores metálicos (zinc, cobre y estaño) determinada por el análisis de distribución de calor. Se concluye que cuanto más baja sea la temperatura de evaporación del precursor, menor será la altura del electrodo de cobre en el sistema. Esto ocurre debido a que con una altura menor la concentración de calor en el contenedor es menor. Este artículo es derivado de una investigación y fue financiado por la Universidad Distrital de Santander.
\end{abstract}

Palabras clave: capa absorbente; Comsol; CZTS; evaporación; elementos finitos; distribución de calor; kesterita; células solares de película fina. 


\section{INTRODUCTION}

Currently, the synthesis of Kesterite type absorber layer with optimal properties for the development of thin-film solar cells is of great interest to the scientific community since its cost/efficiency ratio allows this technology to be commercially competitive. These thin-film solar cells have an optical window/absorber layer configuration where the absorber layer is the active film in the transformation from solar energy to electrical energy [1]. Kesterite type absorber layers $\left(\mathrm{Cu}_{2} \mathrm{ZnSnS}_{4}\right)$ are inorganic films composed of elements with high relative abundance in the earth's crust, a direct band-gap between 1.45 and $1.60 \mathrm{eV}$ and an absorption coefficient greater than $10^{4} \mathrm{~cm}^{-1}$ [2-3-4]. It is also important to mention that photovoltaic systems based on kesterite have high theoretical efficiencies of $32 \%$ [2- 5].

There is research about the synthesis of thin films of kesterite by chemical or physical methods in solution or vacuum. Among vacuum evaporation processes are especially notable synthesis by sputtering and synthesis by evaporation [6-7-8]. The latter are interesting for their easy transition at the commercial level [9-10].

In 2015, Lee et al. [11] reported an efficiency of $11.6 \%$ for the Cztss by evaporation. This efficiency is currently the highest value obtained by evaporation. Despite this, solar cells based on kesterites show low efficiencies. This is mainly due to the formation of secondary phases and crystalline defects in the absorber layer [3-6-12-13].

The synthesis by evaporation of thin films is made in closed systems. In these chambers, the precursors are deposited inside crucibles and these are heated until reaching the evaporation temperature employing a potential difference; after this, the flow of gas generated allows the precursors to be deposited on a substrate [3].

Performing an adequate analysis of the heat flow is essential for the design of heating systems and the proper distribution of the precursors for the synthesis of the films with the established evaporation sequence. Without this, the precursor would evaporate at a non-corresponding stage. For this reason, it is vital to understand and analyze the heat flow phenomena that intervene in the evaporation process. This work has focused on analysis by finite elements through Comsol of disposal of the crucibles, taking into account the system's heat flow to determine an adequate distribution that allows for the kesterites synthesis.

Nonetheless, it is essential to keep in mind that the vacuum chambers could also be used in research or industrial applications. They can be found in different areas among which can be highlighted the optics used to build anti-reflective coatings, mirror protectors, beam splitters or filters; in electronics, for making integrated circuits and 
micro capacitors; and in the metal-mechanical area for coatings, among others sort of applications [14-15].

Heat transfer is made up of heat fluxes by conduction, convection and radiation. However, although some systems present all three distribution processes, this analysis will focus on conduction distribution since it is the phenomenon most important in vacuum chambers.

\section{MATERIALS AND METHODOLOGY}

\subsection{Initial considerations.}

The analysis by finite element was applied in an evaporation chamber made of 304 stainless steel, with CF 2.75 and CF 6 seals that achieve adequate vacuum pressures for the synthesis process. Figure 1 shows the general configuration of the evaporation system.

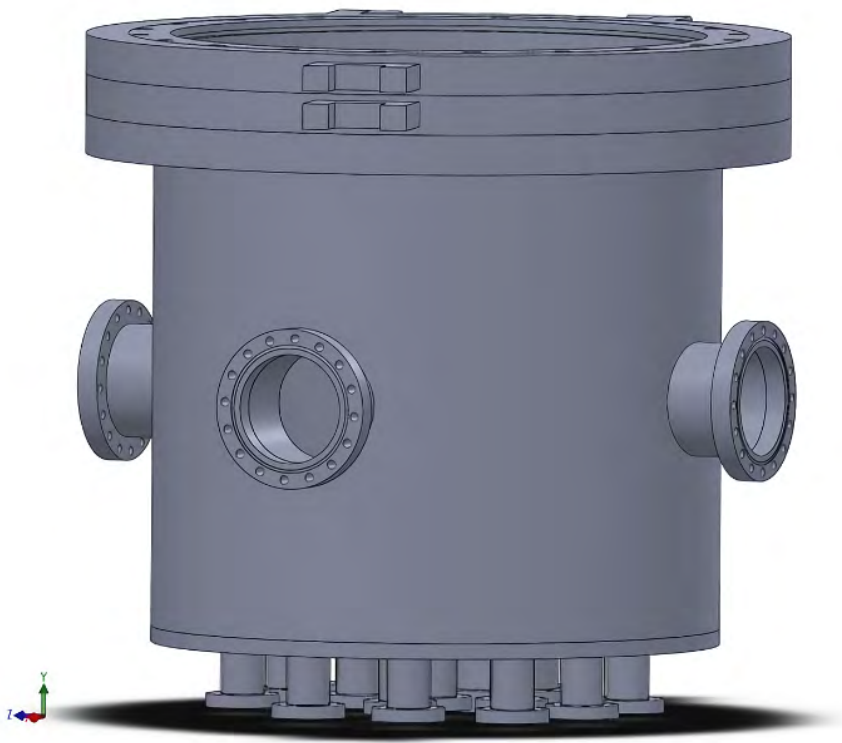

Figure 1. Representative scheme of an evaporation chamber Source: own elaboration.

The heat distribution was analyzed by finite elements, assuming that the precursors are in their elementary state ( $\mathrm{Zn}, \mathrm{Cu}$ y $\mathrm{Sn}$ ) and will be deposited in tungsten crucibles. In contrast, the sulfur will be deposited in the Knudsen cell. Evaporation temperatures are $1017,250,997 \mathrm{y} 150{ }^{\circ} \mathrm{C}$ for the copper, zinc, tin, and sulfur respectively. These values correspond to vacuum pressures close to $10^{-4}$ mbar [16-17]. 
In the analysis model, sulfur will always evaporate while $\mathrm{Cu}, \mathrm{Zn}$, and $\mathrm{Sn}$ will be evaporating in stages. Therefore, it is necessary to establish a design for the evaporation system and the distribution of precursors in crucibles in such a way that the heat generated in each stage doesn't trigger the evaporation of the rest of the precursors.

\subsection{Software for finite element analysis}

A CAD (Computer-aided design) tool and a CAE (Computer-aided engineering) tool were used to perform this research. From the Solidworks (CAD) graphic tool, electrode distribution designs were made and using the Comsol (CAE) tool.

\subsection{Methodology}

An initial model was constructed using the Solidworks tool, and three simulations were carried out using the Comsol tool. In the simulation, an initial distribution of the metal precursors was established in the tungsten crucibles. The simulation was carried out using the evaporation temperatures of study elements and room temperature as boundary conditions. The simulation was carried out by setting on the crucible and the Knudsen cell the evaporation temperature of $\mathrm{Cu}$ and $\mathrm{S}$ as input values. In contrast, the ambient temperature was established as boundary condition on the lower surface of each electrode, and the rest of the surface of the chamber the boundary condition was set $25^{\circ} \mathrm{C}$ as the initial reference temperature. This process was carried out in the same way for the two remaining simulations, substituting the temperature $\mathrm{Sn}-\mathrm{S}$ in the second and $\mathrm{Zn}-\mathrm{S}$ in the third. Subsequently, the analysis of the results was realized to establish whether a new distribution needed to be analyzed or if the proposed model would be modified.

\section{RESULTS AND DISCUSSION}

\subsection{Model Construction using Solidworks}

A model of the evaporation system was developed using Solidworks, taking into account that precursors will be deposited in Tungsten crucibles (copper-tin-zinc) and a Knudsen tantalum cell (sulfur). Figure 2 shows electrode distribution. 
a)

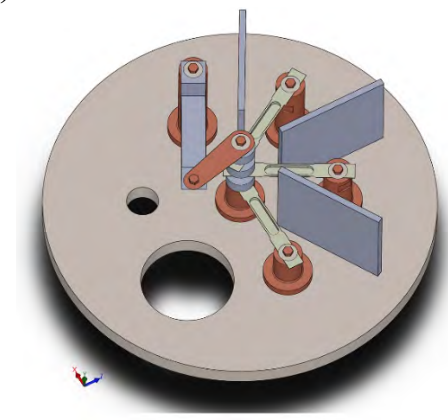

b)

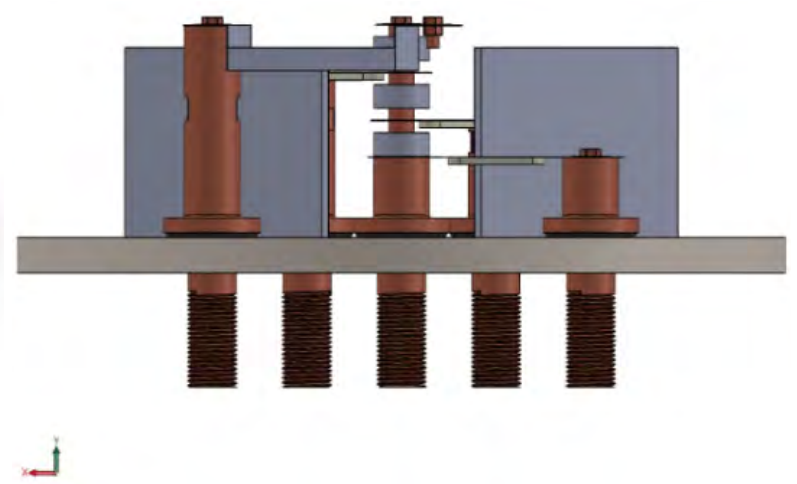

Figure 2. Electrode distribution a) top view b) side view.

Source: own elaboration.

The design consists of five electrodes. One is the common electrode, and the remaining four electrodes are different heights for the distribution of the crucibles. The system is also composed of copper and alumina cylinders. The former is used to increase the electrical contact of the crucibles with the common electrode, and the latter is used to reduce the heat flow to the precursor's crucibles so that the precursors are not evaporated in the previous stage. Figure 3 shows the initial distribution of the precursors in the model.

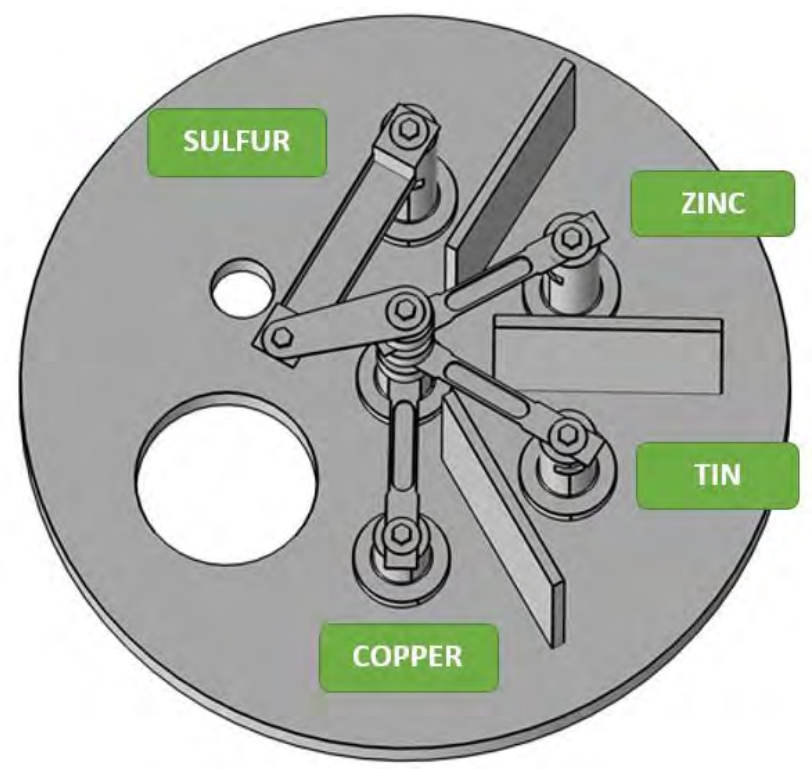

Figure 3. The initial distribution of precursors in the study system Source: own elaboration. 


\subsection{Finite Element Analysis using COMSOL}

Simulation processes by finite elements method were carried out through the Comsol 5.2 a tool. The heat transfer interfaces were used, and the heat transfer in solids was modeled, presenting in all studies a total number of finite elements equal to 2,303,869 with an element radius of $4.67 \times 10^{-11} \mathrm{~cm}$ and an average element quality of 0.66 . In these trials, a working overage time of 1,835 seconds was obtained. The distribution of finite elements is shown in figure 4.

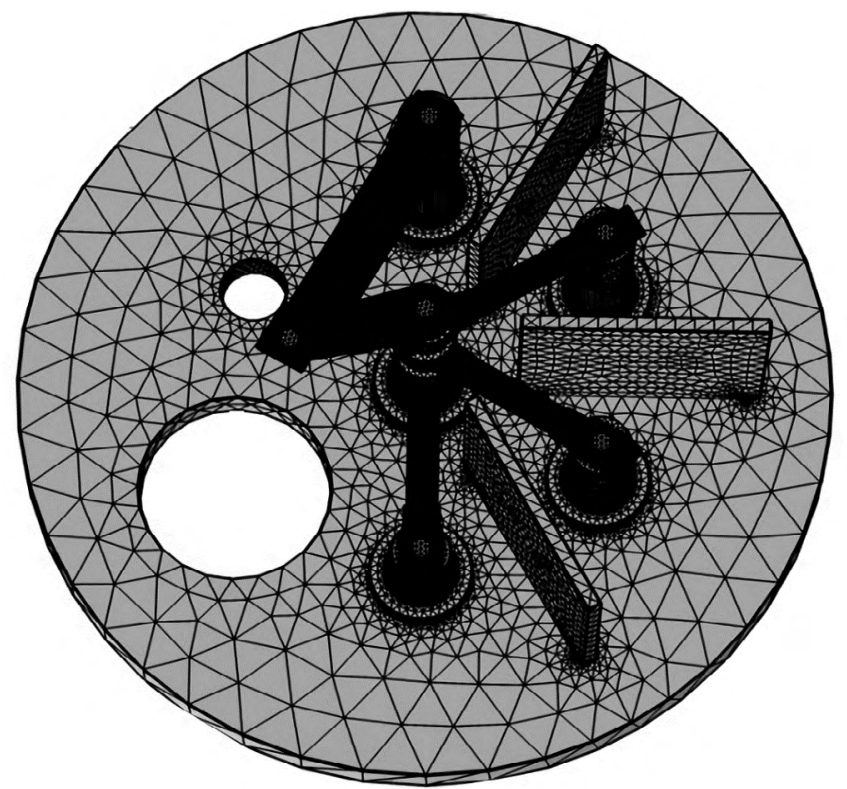

Figure 4.The mesh of finite elements Source: own elaboration.

The input properties of each material were obtained from the library of Comsol. The parameters from each element are showed in table 1. Simulation processes were carried out on stationary study. 


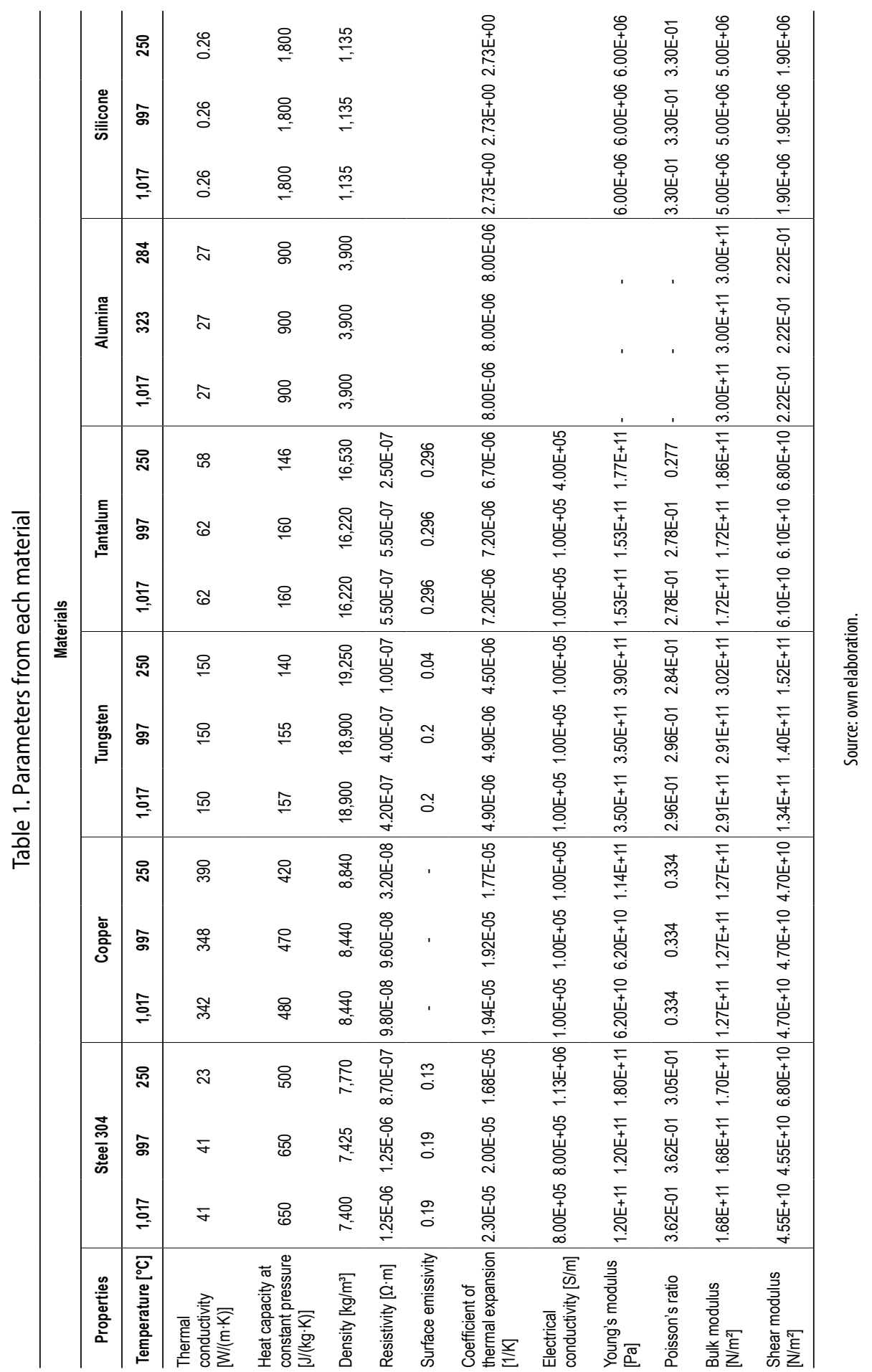


Equations 1 and 2 that model the simulations performed are given below

$$
\begin{gathered}
\rho C_{p} \boldsymbol{u} \cdot \nabla T+\nabla \cdot \boldsymbol{q}=0 \\
\boldsymbol{q}=-k \nabla T
\end{gathered}
$$

Where:

$C_{p}=$ Heat capacity at constant pressure.

$k=$ Thermal conductivity.

$\rho=$ Density

\subsubsection{Initial Model Simulation - Comsol}

The results shown in figure 5 were obtained from the initial model.

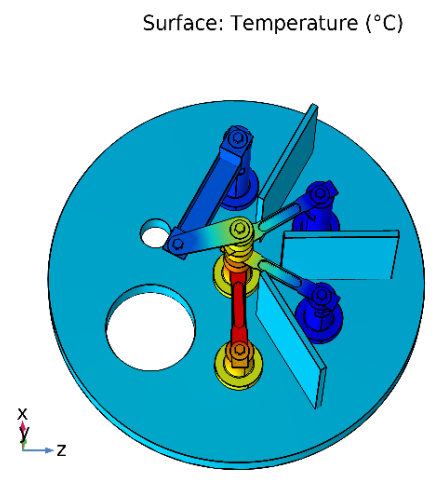

a) $\mathrm{S}-\mathrm{Cu}$

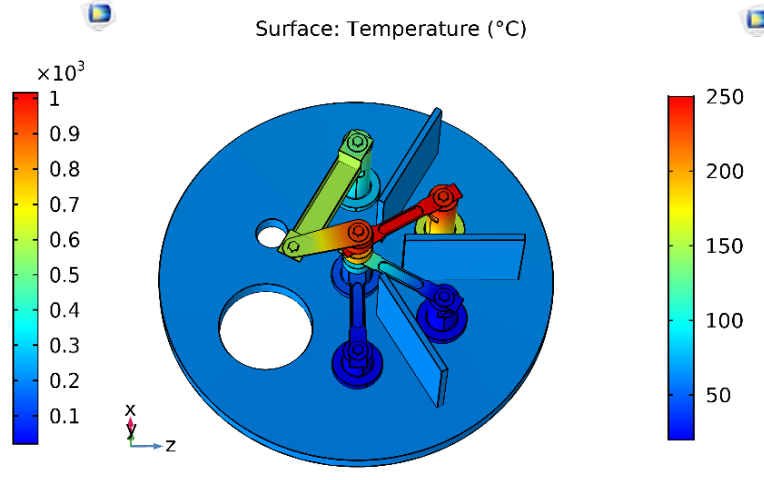

b) S-Sn

Surface: Temperature $\left({ }^{\circ} \mathrm{C}\right)$

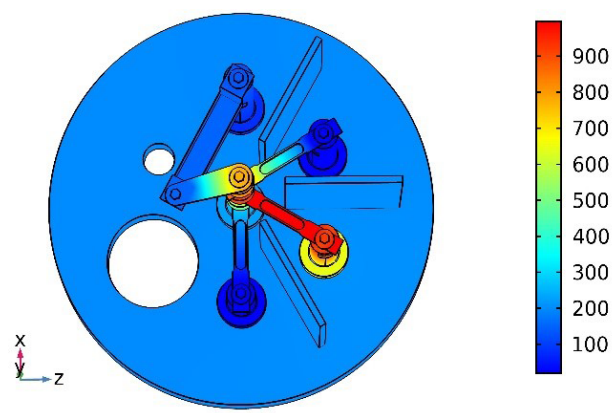

c) S-Zn

Figure 5. Temperature variation $\left({ }^{\circ} \mathrm{C}\right)$ of the different evaporation stages in the system. a) Evaporation of $S$ and $(\mathrm{Cu}$ b) Evaporation of $\mathrm{S}$ and $\mathrm{Sn}$ c) Evaporation of $\mathrm{S}$ and $\mathrm{Zn}$ 
Table 2. Average temperatures on the evaporation surfaces during each stage

\begin{tabular}{ccccc}
\hline \multirow{2}{*}{$\begin{array}{c}\text { Evaporation } \\
\text { stages }\end{array}$} & \multicolumn{4}{c}{ Average temperature of the crucible $\left[{ }^{\circ} \mathrm{C}\right]$} \\
\cline { 2 - 5 } & $\mathrm{Cu}$ & $\mathrm{Sn}$ & $\mathrm{Zn}$ & $\mathrm{S}$ \\
\hline $\mathrm{S}-\mathrm{Cu}$ & $1,017.0$ & 323.3 & 284.0 & 150 \\
$\mathrm{~S}-\mathrm{Sn}$ & 146.1 & 997.0 & 345.2 & 150 \\
$\mathrm{~S}-\mathrm{Zn}$ & 36.1 & 71.5 & 250 & 150 \\
\hline
\end{tabular}

Source: own elaboration.

Table 2 shows the average temperatures of the crucibles, where the precursors will be evaporated. Temperatures in the blue boxes correspond to the evaporation temperatures of the precursors at pressures close to $10^{-4} \mathrm{mbar}$, temperatures in the green boxes confirm that the precursors in the corresponding stages will not evaporate. Finally, the temperatures in the red boxes represent the precursors that evaporate in the stages not corresponding to their evaporation stage.

From the results obtained, it has been determined that while maintaining the sequence of evaporation $\mathrm{Cu}-\mathrm{Sn}-\mathrm{Zn}$ with the distribution present in figure 3, the zinc will evaporate before its corresponding stage. This is because during the evaporation of copper or tin the average temperature of a zinc crucible exceeds $250^{\circ} \mathrm{C}$. Therefore, a change in the distribution of the crucibles or a prior evaporation of zinc is proposed.

However, to maintain the initial evaporation sequence, an analysis of the model is proposed, changing the distribution of the electrodes. Although there are six different potential distributions, only one more will be analyzed since placing copper next to zinc is not an option. This is because copper is the precursor with the highest evaporation temperature, and therefore the zinc precursor will be affected. Following this, an analysis of the configuration in figure 6 is proposed.

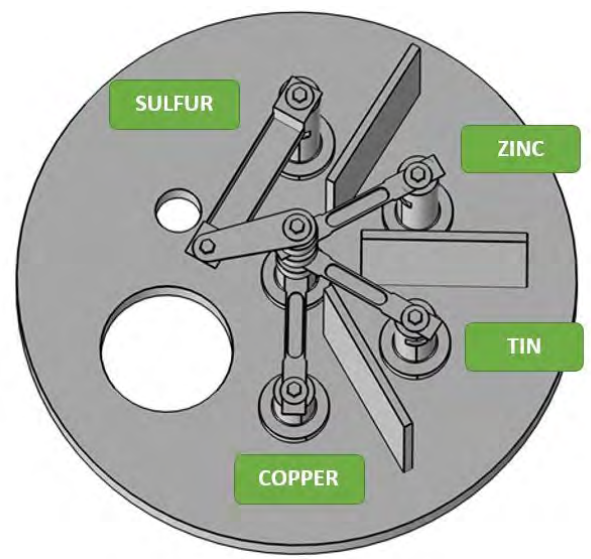

Figure 6. Second distribution of the precursors in the system Source: own elaboration. 


\subsubsection{Simulation of the second model of distribution with Comsol}

The results shown in figure 7 were acquired from the second distribution of the electrodes (figure 6).

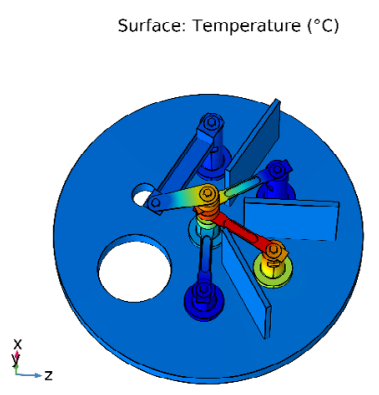

a) $\mathrm{S}-\mathrm{Cu}$

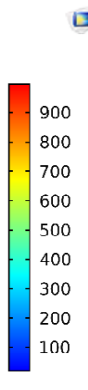

口

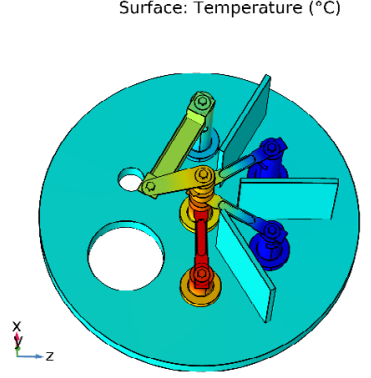

b) S-Sn

Surface: Temperature $\left({ }^{\circ} \mathrm{C}\right)$

$\square$

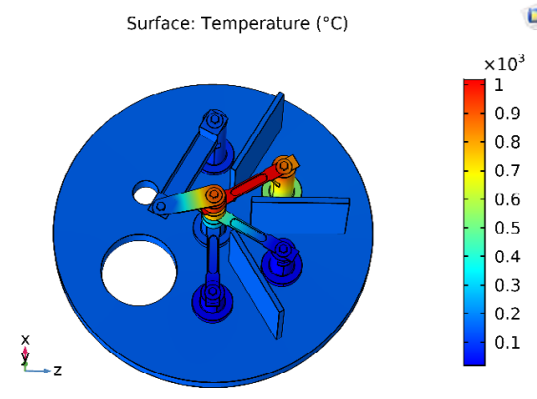

c) S-Zn

Figure 7. Temperature $\left({ }^{\circ} \mathrm{C}\right)$ of the different evaporation stages in the system. a) Evaporation of $\mathrm{S}$ and $\mathrm{Cu}$ b) Evaporation of $\mathrm{S}$ and $\mathrm{Sn}$ c) Evaporation of $\mathrm{S}$ and $\mathrm{Zn}$

Source: own elaboration.

From the results shown in table 3, it has been possible to confirm that none of the precursors reaches the evaporation temperature in a non-corresponding stage. Therefore, it has been established that this distribution may be suitable for the evaporation process. However, it is necessary to analyze the maximum temperatures and the surface temperature distribution in contact with the zinc precursor.

Table 3. Average temperatures on the evaporation surfaces during each stage

\begin{tabular}{ccccc}
\hline \multirow{2}{*}{$\begin{array}{c}\text { Evaporation } \\
\text { stages }\end{array}$} & \multicolumn{4}{c}{ Average temperature of the crucible $\left[{ }^{\circ} \mathrm{C}\right]$} \\
\cline { 2 - 5 } & $\mathrm{Cu}$ & $\mathrm{Sn}$ & $\mathrm{Zn}$ & $\mathrm{S}$ \\
\hline $\mathrm{S}-\mathrm{Cu}$ & 1017.0 & 230.4 & 90.0 & 150 \\
$\mathrm{~S}-\mathrm{Sn}$ & 360.6 & 997.0 & 148.4 & 150 \\
$\mathrm{~S}-\mathrm{Zn}$ & 95.5 & 99.6 & 250.0 & 150 \\
\hline
\end{tabular}

Source: own elaboration. 


\subsubsection{Simulation of the surface in contact with the $\mathrm{Zn}$ precursor with Comsol}

It is important to know the maximum temperature and temperature distribution on the contact surface between the crucibles and the zinc precursor. However, this analysis has been performed assuming that the precursors are particulate. Since there is a greater surface area, the precursor can evaporate at a temperature lower than the evaporation temperature of zinc at pressures close to $10^{-4} \mathrm{mbar}$. This study has been limited to a maximum surface temperature equal to $200{ }^{\circ} \mathrm{C}$ for the zinc crucible. Figure 8 shows the analysis surface and its temperature variation.
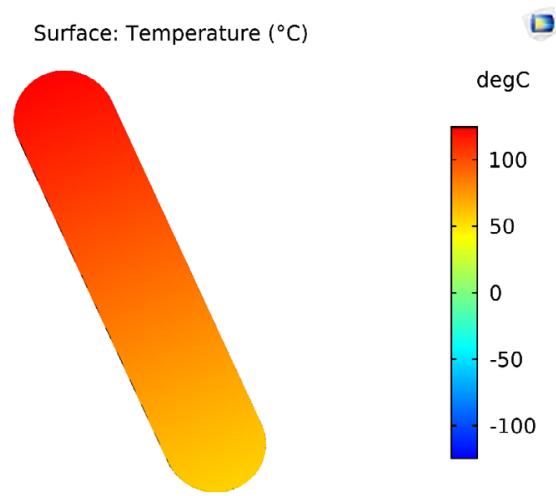

Figure 8. Temperature distribution in the $\mathrm{Zn}$ crucible

Source: own elaboration.

The results shown in the figure 9 were obtained from the simulations performed on the surface in contact with zinc during the evaporation process of copper and tin precursors.

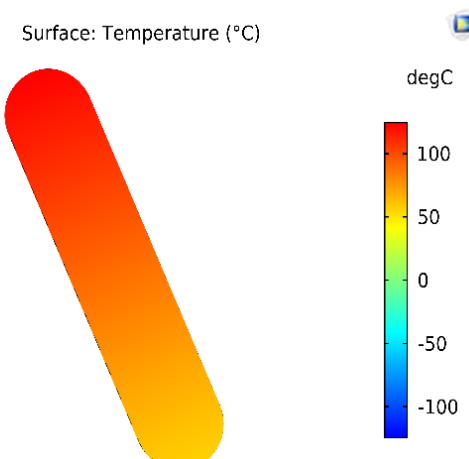

a) Evaporation of $\mathrm{Cu}$

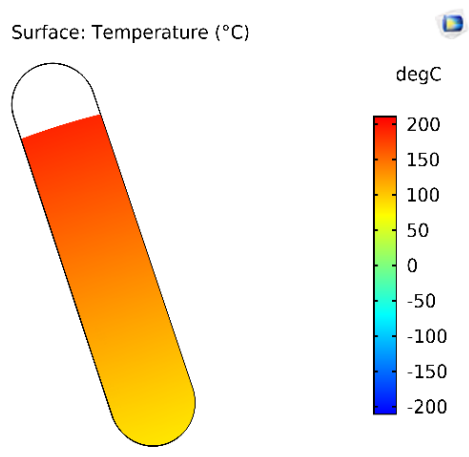

b) Evaporation of $\mathrm{Sn}$

Figure 9. Temperature distribution in the $\mathrm{Zn}$ crucible. a) Evaporation of $\mathrm{Cu}$ b) Evaporation of Sn Source: own elaboration. 
With the results obtained, it was established that approximately $20 \%$ of the surface of the zinc crucible exceeds $200{ }^{\circ} \mathrm{C}$ at the stage of tin evaporation, thus decreasing the efficiency of electrodes distribution. Maximum temperatures were determined to establish the importance of adjusting the model and obtaining greater efficiency in the evaporation process. The results obtained are displayed in table 4 .

Table 4. Maximum temperatures at the evaporation surface of zinc

\begin{tabular}{cc}
\hline \multirow{2}{*}{ Evaporation stages } & \multicolumn{2}{c}{ Maximum temperature zn } \\
& \multicolumn{1}{c}{$T\left[^{\circ} \mathrm{C}\right]$} \\
\hline$S-C u$ & 124.6 \\
$S-S n$ & 214.5 \\
$S-Z n$ & 200.0 \\
\hline \multicolumn{2}{c}{ Source: own elaboration. }
\end{tabular}

In the tin evaporation stage, the maximum temperature for $\mathrm{Zn}$ was $214.5^{\circ} \mathrm{C}$, a temperature higher than $200^{\circ} \mathrm{C}$. To reduce this variation, an alumina cylinder was incorporated between the tin and zinc crucibles in the common electrode. The system will remain with the second distribution (figure 6). Figure 10 shows a side section of the model.

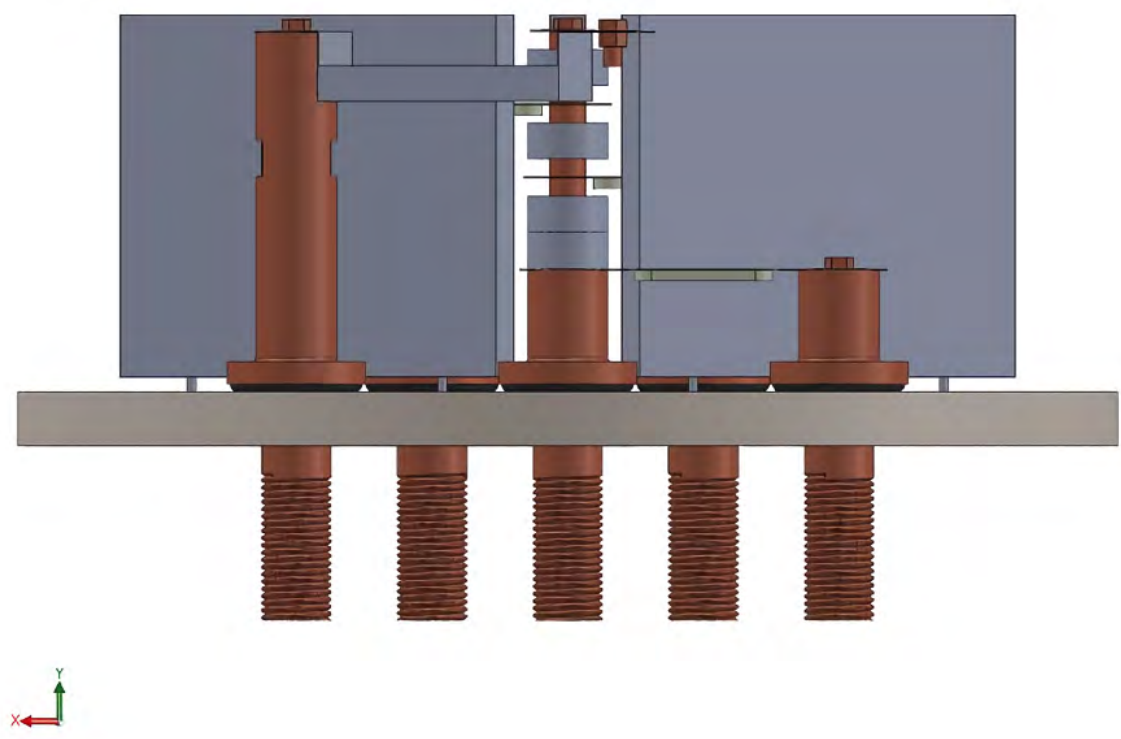

Figure 10. Second distribution including alumina cylinder in the common electrode between the zinc and the tin crucibles

Source: own elaboration. 


\subsubsection{Model simulation incorporating an alumina cylinder - Comsol}

After the second distribution and the incorporation of the alumina in the cylinder, the results shown in the figure 11 were obtained.

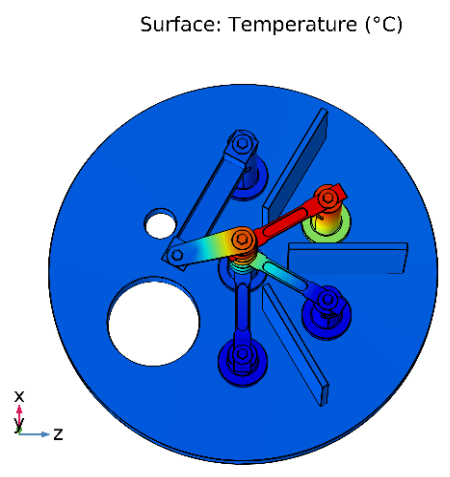

a) Cu-S

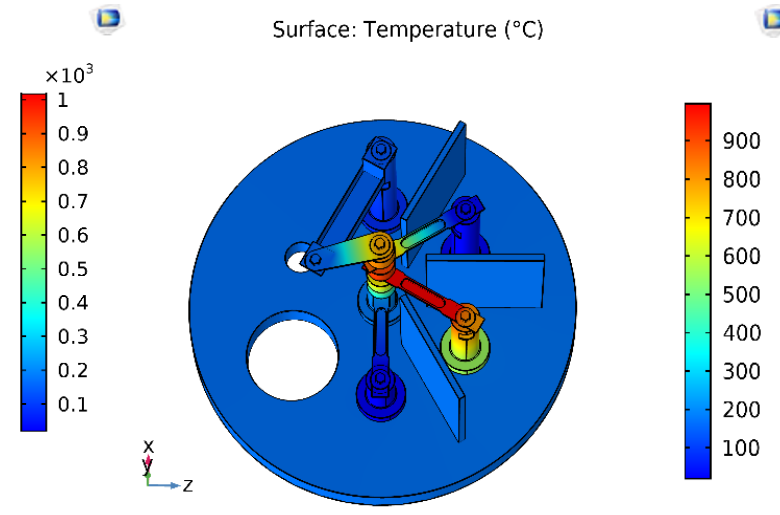

b) Sn-S

Surface: Temperature $\left({ }^{\circ} \mathrm{C}\right)$

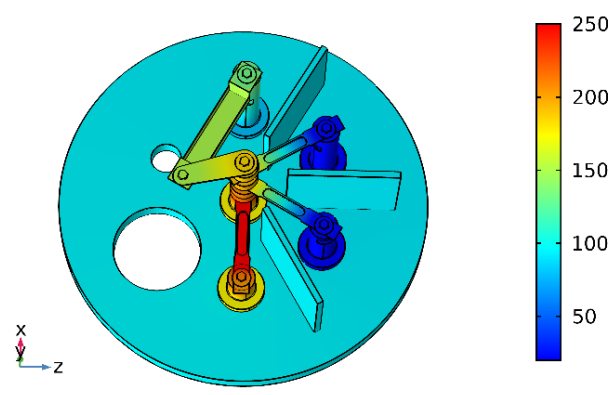

c) Zn-S

Figure 11. Temperature $\left({ }^{\circ} \mathrm{C}\right)$ of the different evaporation stages. a) Evaporation of $\mathrm{S}$ and $\mathrm{Cu}$

b) Evaporation of S and Sn c) Evaporation of S and Zn

Source: own elaboration.

From the results obtained, it is established that none of the precursor elements will evaporate at a non-corresponding stage during the synthesis process. Therefore, it is recommended to use the distribution presented in the second study together with the dimensions of the electrodes and materials that have been used to perform the synthesis of CZTS with the evaporate sequence $\mathrm{Cu} / \mathrm{Sn} / \mathrm{Zn}$ in the sulfur atmosphere. Table 5 shows the maximum temperatures at the evaporation surface of zinc. 
Table 5. Maximum temperatures at the evaporation surface of zinc

\begin{tabular}{cc}
\hline \multirow{2}{*}{$\begin{array}{c}\text { Evaporation } \\
\text { stages }\end{array}$} & Zn maximum temperature \\
\cline { 2 - 2 } & $\mathrm{T}\left[{ }^{\circ} \mathrm{C}\right]$ \\
\hline S-Cu & 109.9 \\
S-Sn & 166.4 \\
S-Zn & 200.0 \\
\hline \multicolumn{2}{c}{ Source: own elaboration. }
\end{tabular}

\section{CONCLUSIONS}

In the paper, the simulation of finite elements to the heat distribution in an evaporation system designed for the synthesis of CZTS is presented. The evaporation sequence of the precursors was $\mathrm{Cu}-\mathrm{Sn}-\mathrm{Zn}$. The distribution selected as the best option to evaporate each precursor in the corresponding stage was the second with alumina included in the central electrode. Finally, it is concluded that the lower the precursor evaporation temperature, the height of the electrode in which the crucible will be installed must also be lower because the heat will have less material in the direction of flow and its heat concentration in the crucible will be reduced.

\section{REFERENCES}

[1] R. H. Bube, Photovoltaic materials: properties of semiconductor materials. Imperial Collage press, 1998.

[2] J. C. Gonzáles, A. Abelenda, and M.Sanchez.Caracterización de capas delgadas de $\mathrm{Cu}_{2} \mathrm{ZnSnS}_{4}$ para aplicaciones fotovoltaicas. Habana: Universidad de la Habana, 2016.

[3] S. Xiangbo, J. Xu, L. Ming, L. Weidong, L. Xi, and Z. Hua. "A review on development prospect of CZTS based thin film solar cells". HindawiLimited; International Journal of Photoenergy, vol 2014, p 1-11, 2014. http://dx.doi.org/10.1155/2014/613173

[4] S. Thiruvenkadam, et al.,"Effect of $\mathrm{Zn} / \mathrm{Sn}$ molar ratio on the microstructural and optical properties of $\mathrm{Cu}_{2} \mathrm{Zn}_{1-\mathrm{x}} \mathrm{Sn}_{\mathrm{x}} \mathrm{S}_{4}$ thin films prepared by spray pyrolysis technique". Physica B: Condensed Matter, vol 533, pp 22-27. https://doi.org/10.1016/j.physb.2017.12.065

[5] J. B.Carda, T.Stoyanova, and R.Martí. "Obtención de estructuras calcopirita (CIGS) y kesterita (CZTS) como absorventes para dispositivos fotovoltaicos de capa fina mediante métodos de síntesis de bajo coste". Ph. D. dissertation. Castellon de la Plana. Universitat Jaume I de Castellon, Castellon, 2016, p 228.

[6] Y.P. Lin, Y. F. Chi, T. E. Hsieh, Y. C. Chen, and K.P. Huang. "Preparation of $\mathrm{Cu}_{2} \mathrm{ZnSnS}_{4}(\mathrm{CZTS})$ sputtering target and its application to the fabrication of CZTS thin-film solar cells." Journal of Alloys and Compounds, vol. 654, pp. 498-508. 2016. 10.1016/j.jallcom.2015.09.111 
[7] U. Chalapathi, S. Uthanna, and V. Sundara Raja."Growth of $\mathrm{Cu}_{2} \mathrm{ZnSnS}_{4}$ thin films by co-evaporation-annealing route: effect of annealing temperature and duration”. Journal of Materials Science: Materials in Electronics, vol. 27, pp. 1048-1057, 2018. https://doi. org/10.1007/s10854-017-8005-0

[8] T. Tunaka, et al. "Influence of composition ratio on properties of $\mathrm{Cu}_{2} \mathrm{ZnSnS}_{4}$ thin film fabricated by co-evaporation”. Thin Solid Films, vol. 518, pp. S29-S33, 2010. https://doi. org/10.1016/j.tsf.2010.03.026.

[9] E. Garcia Llamas, et al. " $\mathrm{Cu}_{2} \mathrm{ZnSnS}_{4}$ thin film solar cells grown by fast thermal evaporation and thermal treatment.” Solar Energy, vol. 141, pp. 236-241. 2017. http://dx.doi.org/10.1016/j. solener.2016.11.035

[10] M. Neuschitzer, E. Saucedo, and A. Pérez. Development of $\mathrm{Cu}_{2} \mathrm{ZnSnS} \mathrm{S}_{4}$ based thin film solar cells by PVD and chemical based processes. Ph. D. dissertation. España. Barcelona. Universidad de Barcelona, 2016, p 138.

[11] S. Y. Lee, et al. "“Cu2ZnSnS4 thin-film solar cells by thermal co-evaporation with $11.6 \%$ efficiency and improved minority carrier diffusion length". Advance Energy Materials, vol. 5. 2015. https://doi.org/10.1002/aenm.201401372

[12] X. Fontané Sanchez, A. Pérez Rodriguez, and V.Izquerdo Roca.Caracterización por espectroscopia Raman de semiconductores $\mathrm{Cu}_{2} \mathrm{ZnSnS}_{4}$ para nuevas tecnologías fotovoltaicas, Barcelona: Universidad de Barcelona, 2011, pp. 138.

[13] Shiyou C. " $\mathrm{Cu}_{2} \mathrm{ZnSnS}_{4} \mathrm{Cu}_{2} \mathrm{Zn}(\mathrm{SnSe})_{4}$, and related materials." Semiconductor Materials for Solar Photovoltaic Cells, vol 218, pp. 75-103, 2016.

[14] L. Escobar Alarcón, E. Rincón Mejía and S. Chirino Ortega. Diseño de una cámara para el depósito de películas delgadas por ablación laser. Ph. D. dissertation. México, Universidad Autónoma del Estado de México, 2001, pp. 4.

[15] C. Villamizar and J. Duarte. "Construcción de sistemas de presión en el intervalo de medio y alto vacío.” MET y FLU. pp. 35-47. 2019.

[16] I. Gutiérrez Ortuño, Tratamiento y modificaciones de superficiales del acero. Provincia de Cádiz: Universidad de Cádiz, 2009, pp. 41.

[17] M. Hurtado, G. Gordillo and E. Romero Malagón. Síntesis y caracterización de películas delgada del semiconductor $\mathrm{Cu}_{2} \mathrm{ZnSnS}_{4}$ y su uso como capa absorbente en celdas solares. Bogotá D.C: Universidad Nacional de Colombia. 2014. pp. 42. 